Hana Červinková

https://doi.org/10.26881/pwe.2020.51.04

ORCID: 0000-0002-1333-1349

Maynooth University, Ireland

hana.cervinkova@mu.ie

\title{
Miejsca kultury w antropologii i etnografii edukacyjnej
}

\section{Summary}

\section{Locations of culture in educational anthropology and ethnography}

The focus of this article is on culture as a central concept of educational anthropology - a subdiscipline of anthropology that focuses on the fields of education and learning as key aspects of social life. It begins with an introduction into how culture has been criticially conceptualized in anthropology and ethnography and then illustrates how educational anthropologists have used the concepts of culture and cultural critique to analyze educational processes in diverse sociocultural settings. The author points out three primary areas in which anthropology of education enriches our understanding of education and learning: 1) investigations of diversity of educational practices in different sociocultural contexts; 2) critical examination of cultural practices and structures of inequality and exclusion vis-à-vis minority subjects in the educational process; 3 ) positioning of participatory research approaches and engagement as legitimate methodological and scholary standpoints. The article builts primarily on examples of texts that have been recently published in the Polish language in order to help situate the perspective of educational anthropology in Polish scholarly discourse and tradition.

Keywords: culture, education, anthropology, ethnography, critique, diversity

Słowa kluczowe: kultura, edukacja, antropologia, etnografia, krytyka, różnorodność

\section{Wstęp}

Pojęcie „kultura” pozostaje kluczowe w obrębie antropologii kulturowej i społecznej od czasu instytucjonalizacji tej dyscypliny na początku XX w. Kultura jest soczewką, przez którą antropolodzy obserwują i analizują podobieństwa i różnorodność ludzkich doświadczeń - odnosząc się z jednej strony do „kultury człowieka” jako powszechnego ludzkiego fenomenu, a z drugiej do konkretnej „kultury” lub „kultur” jako specyficznych przejawów bycia człowiekiem w konkretnych okolicznościach geopolitycznych i historycznych (Wagner 2005). Kultura pozostaje tak ściśle powiazana z antropologią, że „możemy nazwać antropologiem kogoś, kto ma zwyczaj używać terminu »kultura« mówiąc o świecie społecznym" (Wagner 2005: 59). Mimo że pojęcie to poddane zostało krytyce epistemologicznej w minionym stuleciu, wciąż wyznacza sposób, w jaki antropolodzy 
przedstawiają i objaśniają proces codziennego dyskursu społecznego, w tym praktyki edukacyjne. W niniejszym artykule skupiłam się na kulturze jako centralnym pojęciu antropologii edukacyjnej - subdyscypliny antropologii, która bada społeczno-kulturowe osadzenie edukacji formalnej i nieformalnej. Chciałam wykazać, w jaki sposób kultura i krytyka kultury umożliwiają antropologom edukacyjnym wprowadzenie wyjątkowej, krytycznej perspektywy do kontekstualizacji społeczno-kulturowej procesów edukacyjnych.

Na początku dokonałam krótkiego przeglądu głównych powiązań między kulturą i etnografią w antropologii. Następnie przedstawiłam kilka przykładów badań z zakresu antropologii edukacyjnej w celu zilustrowania, w jaki sposób antropolodzy stosują pojęcie kultury i krytyki kultury w analizie procesów edukacyjnych przebiegających w różnorodnych kontekstach spoleczno-kulturowych. Chciałam przybliżyć potencjał takiego podejścia w trzech głównych obszarach: 1) w badaniu praktyk edukacyjnych w różnorodnych kontekstach społeczno-kulturowych; 2) w krytycznej analizie praktyk kulturowych oraz struktur nierówności i wykluczenia przedstawicieli mniejszości w procesie edukacyjnym; 3) w pozycjonowaniu i zastosowaniu zaangażowania oraz uczestniczących podejść badawczych jako uprawnionych perspektyw naukowych i metodologicznych.

\section{Konstrukcje kultury w antropologii i etnografii}

Główne miejsce kultury i kultur w antropologii wynika z jej zakorzenienia w etnograficznych badaniach społeczności spoza świata Zachodu. O ile najbliżsi kuzyni antropologii socjologia i etnologia (w swojej tradycji folklorystycznej) koncentrowały się głównie na badaniu różnych aspektów narodowych i lokalnych kultur głównie w obrębie społeczności Zachodu, o tyle antropologię wyróżnia wyraźne zainteresowanie odległym Innym. Podmioty antropologii, nazywane „,prymitywnymi”, „dzikimi”, „niepiśmiennymi”, odnajdywano głównie w geopolitycznych dominiach skolonizowanego Trzeciego Świata, a ich badanie przez antropologów było stymulowane chęcią zarejestrowania i ocalenia w formie pisemnej różnorodnych stylów życia, zanim zanikną na skutek geopolitycznej ekspansji zachodniego świata. Od momentu ich wprowadzenia badania podmiotów „niezachodnich” i radykalnie innych służyły antropologii również jako punkt odniesienia w krytyce kultury społeczeństw Zachodu.

Antropologiczna wiedza na temat innych kultur jest nierozdzielnie powiązana z etnografią, co zostało dobitnie wyrażone w pionierskiej monografii Bronisława Malinowskiego The Argonauts of Western Pacific (Argonauci zachodniego Pacyfiku) z roku 1922, gdzie opisuje on kulturę Wysp Trobrianda, leżących na wschód od wybrzeża Nowej Gwinei (Malinowski 2005). W pierwszym rozdziale Malinowski nakreśla standardy etnografii jako metody naukowej, która zawiera takie zasady, jak potrzeba rozległych badań prowadzonych na miejscu pośród podmiotów badań antropologa (i separacja od własnej kultury), stosowanie specjalnych metod zbierania danych, wyznaczenie ,autentycznych naukowych celów” oraz znajomość ,zasad i kryteriów współczesnej etnografii” (Malinowski 
2005: 5). Według niego antropologia i etnografia są nierozerwalnie połączone, a „czary etnografa”, do których się odwołuje (Malinowski 2005: 5), polegają na umiejętności wyciągania wniosków ogólnych z konkretnych danych dowodowych zebranych podczas okresu intensywnego zanurzenia w badanej kulturze tak, by móc przedstawić ,punkt widzenia tubylca" (Malinowski 2005: 19). Podejście Malinowskiego do kultury jest holistyczne i funkcjonalistyczne - aby zrozumieć daną kulturę, antropolog, którego nazywa on ,autentycznym pracownikiem prawdziwej Nauki o Człowieku”, musi pojąć całość jej elementów. „To miłość do ostatecznej syntezy osiągniętej przez asymilację i zrozumienie wszystkich przejawów kultury, oraz, co więcej, umiłowanie różnorodności i niezależności rozmaitych kultur definiuje ostatecznie autentycznego pracownika prawdziwej Nauki o Człowieku" (Malinowski 2005: 407).

Jako pozytywista Malinowski traktuje kulturę ahistorycznie - jest to zamknięty, powiązany wewnętrznie system, który może być badany obiektywnie przez antropologa za pomocą metody etnograficznej. Nawet we wczesnym okresie rozwoju dyscypliny antropologii, kiedy pozytywizm panował niepodzielnie, możemy dostrzec silnie zarysowany element krytyki kulturowej. Powodem, dla którego badamy życie Innego, jest pogłębienie zrozumienia ludzkiej różnorodności i zastosowanie tej wiedzy w konstruktywnej krytyce naszej kultury: „Zyskując podstawowy wgląd w innych w duchu szacunku i autentycznego zrozumienia należnemu nawet dzikim, jednocześnie poszerzamy wgląd w nas samych. Nie możemy osiągnąć pełnej, sokratycznej samowiedzy, jeśli nigdy nie porzucimy ograniczeń narzuconych przez zwyczaje, przekonania i uprzedzenia, pośród których wyrastamy. Nic nie może nam udzielić lepszej lekcji w tej niezwykle ważnej kwestii niż nawyk myślowy, który pozwala nam patrzeć na przekonania i wartości wyznawane przez innych z ich własnego punktu widzenia. Ani też nigdy wcześniej cywilizowana ludzkość nie potrzebowała takiej tolerancji bardziej niż dzisiaj, kiedy przesąd, zła wola i mściwość oddzielają europejskie narody od siebie, kiedy wszystkie ideały, hołubione i ogłoszone najwyższymi osiągnięciami cywilizacji, nauki i religii rozwiały się. Nauka o Człowieku, w swojej najczystszej i najgłębszej wersji powinna prowadzić nas do wiedzy, tolerancji i wielkoduszności opartych na zrozumieniu punktu widzenia innego człowieka" (Malinowski 2005: 407).

Kiedy w kolejnych dekadach XX w. metodologiczny pozytywizm nauk humanistycznych i społecznych zostaje poddany wnikliwej analizie, antropolodzy zaczynają zwracać szczególną uwagę na konstruowaną naturę wiedzy antropologicznej opartej na relacyjnym i osobistym doświadczeniu w trakcie badań terenowych. W znanej pracy Clifford Geertz (2005) zwraca uwagę na semiotyczne podwaliny kultury - porównuje ją do sieci znaczeń, którą sami stworzyliśmy i w której jesteśmy zawieszeni. Tę tworzącą kulturę sieć znaczeniową można dostrzec w praktykach życia codziennego. Zadaniem antropologa jest odczytywanie i analiza społecznego dyskursu i jego zapis w formie opisu gęstego - nasyconego interpretacyjnie kulturowego przekazu, który polega nie na nagromadzeniu faktów, ale na ich wielopoziomowych interpretacjach (Geertz 2005). 
Roy Wagner idzie krok dalej i mówi o procesie, w którym antropolodzy obiektywizują przebieg życia społecznego obserwowanego podczas badań etnograficznych jako o wynajdowaniu kultury. Za pomocą opisu etnograficznego antropolodzy stają się wynalazcami kultury - Innego i własnej: „Przed podjęciem badań etnograficznych badacz nie miał kultury, gdyż kultura, w której się wzrasta, nigdy nie jest »widzialna«, jest przyjmowana bezrefleksyjnie, a jej założenia wydają się oczywiste. (...) Tylko przez doświadczenie kontrastu z inną, własna kultura staje się dla badacza »widzialna«. W akcie wynajdowania innej kultury antropolog odkrywa swoją własną..." (Wagner 2005: 62). W akcie poznawania - obserwacji i opisu - innej kultury antropolog odkrywa własną i faktycznie wynajduje pojęcie samej kultury na nowo. Taka rola antropologów jako wynalazców kultury - kultury Innego i ich własnej - pozycja bycia pomiędzy, stanowi jądro antropologicznego wytwarzania wiedzy: „Relacja, jaką antropolog tworzy pomiędzy dwiema kulturami - co z kolei uprzedmiotawia, a przez to, $w$ jego odbiorze, kreuje te kultury - wyrasta $\mathrm{z}$ aktu »wytworzenia«, zastosowania znaczeń znanych z własnej kultury w celu skonstruowania zrozumiałego przedstawienia kultury będącej przedmiotem jego badań. (...) Antropolog nie może po prostu »nauczyć się« nowej kultury i umieścić ją poza tą, którą już zna, lecz powinien "przyjąc ją " po to, by doświadczać przekształceń swego świata" (Wagner 2003: 65-66).

To metodologiczne i ontologiczne umiejscowienie antropologa zarówno pomiędzy, jak i wewnątrz różnych światów kulturowych, które on interpretuje (Geertz 2005) i wynajduje (Wagner 2005), stanowi o potencjale krytyki kulturowej w antropologii - umiejętności naświetlania współczesnych zagadnień z perspektywy transkulturowej (Marcus, Fischer 2010). O takim fundamentalnie transkulturowym sposobie widzenia i opisywania świata wpisanym w antropologiczne wytwarzanie wiedzy często mówi się, że to „czynienie obcego znanym, a znanego obcym". Czynienie obcego znanym odnosi się do faktu, że antropologia potrafi poznawać i opisywać światy innych ludzi z emicznego punktu widzenia. Jednocześnie zaś badania terenowe, które są - jak już wspomniałam - inicjującym przemianę procesem uczenia się, zmuszają antropologów do poddania ich własnego kontekstu kulturowego krytycznej refleksji. Ten właśnie komponent procesu wytwarzania wiedzy skutkuje „czynieniem znanego obcym”. Czynienie obcego znanym, a znanego obcym, czyli umiejętność skontekstualizowanego widzenia etnograficznego i przekładania różnic kulturowych jako cech jednej i tej samej ludzkości, jest jednym z najbardziej charakterystycznych wyróżników badań antropologicznych.

Chociaż współcześni antropolodzy nie zawsze podróżują do odległych egzotycznych krain, aby wynajdować kultury mające się stać obiektem badań, decydują się bowiem na badania stacjonarne, czasem w kilku miejscach (Hannerz 2003). Antropologiczny ,sposób widzenia" - unikatowy sposób przypisywania obserwacjom etnograficznym znaczenia kulturowego oraz przekładanie ich na opisy etnograficzne - wciąż pozostaje fundamentalnym imperatywem metodologicznym (Wolcott 2008). Od lat 80. dzięki prowadzonej przez antropologów dyskursywnej krytyce przedstawienia kulturowego (cultural representation) coraz powszechniej uświadomiano sobie, że opisy kultur mają niepełny i konstrukcyjny charakter i że należy zadawać pytania o relacje władzy i warunki występujące podczas 
ich tworzenia, takie jak: Kto dokonuje opisu? Czyj głos jest słyszany? Kto obserwuje? Kto jest obserwowany? Kto jest na scenie? (Clifford, Marcus 1986; Clifford 2000). Owa krytyka przedstawienia kulturowego była jednym z najważniejszych punktów zwrotnych w historii antropologii. W dużej mierze przyczyniły się do tego także studia postkolonialne i feministyczne. W znanej pracy antropolożka Lila Abu-Lughod zaproponowała wręcz odrzucenie pojęcia kultury jako narzędzia „wytwarzania innego” (othering): „Będąc naukowym dyskursem, który rozwija znaczenie kultury w celu opisu, wyjaśnienia i zrozumienia różnic kulturowych, antropologia również przyczynia się do ich konstruowania, wytwarzania i utrzymywania. Antropologiczny dyskurs nadaje różnicom kulturowym (oraz separacji między grupami ludzi, których dotyczy) atmosferę oczywistości” (2014: 390). Abu-Lughod krytykuje antropologiczne pojęcie kultury za tendencję do esencjalizmu oraz utrwalania różnic, zbytni nacisk na spójność wewnątrz społeczności, które są postrzegane jako ograniczone i dyskretne, oraz za skłonność do pomijania konfliktu i wewnętrznego zróżnicowania kultur. Akhil Gupta i James Fergusson w podobnym duchu dokonują krytyki antropologicznych koncepcji kultury za ich tendencję do łączenia kultury z przestrzenią i tożsamością oraz za ignorowanie faktu, że kultury nie są ograniczone do konkretnego terytorium i przeważa w nich wewnętrzna różnorodność i hybrydowość: „W rozdrobnionej przestrzeni ponowoczesności przestrzeń nie straciła znaczenia: uległa reterytorializacji w taki sposób, że nie odpowiada to już doświadczeniu przestrzeni, które charakteryzowało szczytowy okres nowoczesności. Z tego powodu zmuszeni jesteśmy dokonać fundamentalnej rekonceptualizacji polityki wspólnoty, solidarności, tożsamości i różnicy kulturowej" (2005: 270). Dzięki krytyce dokonanej przez tych oraz wielu innych antropologów udało się naświetlić sposób, w jaki kultura, będąc kluczowym pojęciem antropologicznym, jest nierzadko używana jako kategoria utwierdzająca lub nawet usprawiedliwiająca dyskryminacyjną politykę społeczną, polityczną i ekonomiczną wobec grup uznanych za kulturowo odmienne. Na przykład Norma Gonzáles, antropolożka edukacyjna, słusznie stwierdza, że o ile kultura odegrała ważną rolę $\mathrm{w}$ walce $\mathrm{z}$ biologicznym determinizmem, objaśniając kulturowo i historycznie konstruowaną podstawę ludzkiej różnorodności, o tyle może ona również być w podobny sposób użyta do zamykania ludzi w wyimaginowanym więzieniu kulturowo zdeterminowanych światów (Gonzáles 2010a) . $^{1}$

Antropologowie zajmujący się procesami migracji wskazują, jak „kultura” zostaje zawłaszczana przez populistycznych polityków, którzy posługują się nią do wysuwania twierdzeń o kulturowej odrębności imigrantów, zagrażających kulturowej autentyczności krajów, do których przybywają (Vertovec 2011). Taka krytyka odegrała w antropologii ważną rolę w odejściu od postrzegania kultur jako „statycznych, ujednolicających, terytorialnych bytów i artefaktów wymagających »zachowania«" (Vertovec 2011: 251) i w zmianie obejmującej kontekstualne konstruowanie pojęć kultury, które uwzględniają

\footnotetext{
1 Najbardziej niesławnym przykładem jest „kultura ubóstwa”, argument pochodzący z badań Oscara Lewisa w Meksyku (Lewis 1959), który tłumaczy ubóstwo nie jako uwarunkowanie społeczno-ekonomiczne, lecz jako zjawisko osadzone i zdeterminowane kulturowo.
} 
jej hybrydową, procesualną i dynamiczną konfigurację w rzeczywistości globalnej. Krytycy ci utorowali drogę do bardziej zniuansowanego pojęcia kultury, które pozostaje kluczowe dla antropologów badających i opisujących różnorodność ludzkich światów (Hannerz 2010: 53). W następnej części artykułu wskazałam kilka przykładów ilustrujących, jak antropolodzy edukacji używają koncepcji kultury, aby objaśniać procesy edukacyjne.

\section{Miejsca kultury w antropologii i edukacji}

Subdyscyplina antropologii edukacji jest prężną dziedziną akademicką w Stanach Zjednoczonych, gdzie założona w 1968 r. Rada Antropologii i Edukacji (CAE - Council on Anthropology and Education) jest oficjalnym oddziałem Amerykańskiego Stowarzyszenia Antropologicznego. Przedstawiłam trzy główne obszary, w których - jak uważam antropologia i edukacja wywarły największy wpływ na badania edukacyjne: 1) transkulturowo wrażliwe opisy formalnych i nieformalnych praktyk edukacyjnych w różnorodnych kontekstach społeczno-kulturowych; 2) krytyczna analiza praktyk kulturowych oraz struktur nierówności i wykluczenia przedstawicieli mniejszości w procesie edukacyjnym; 3) integracja uczestniczących podejść badawczych jako uprawnionych metodologicznie i naukowo perspektyw. Przykłady, na które się powołałam, pochodzą głównie z tekstów amerykańskich autorów, których prace są dostępne w języku polskim - wiele z nich ukazało się w wydanej w 2019 r. antologii Antropologia i edukacja. Etnograficzne badania w tradycji amerykańskiej (Červinková 2019a).

\section{Formalne i nieformalne praktyki edukacyjne w różnorodnych kontekstach spoteczno-kulturowych}

Opisy rozmaitych praktyk wychowawczych oraz osadzonych w rodzinie i społeczności procesów uczenia się stanowiły integralną część wielu opisów etnograficznych innych kultur nawet przed oficjalną instytucjonalizacą antropologii edukacyjnej. Jednym z wczesnych i powszechnie znanych badań poświęconych bezpośrednio edukacji było studium etnograficzne samoańskich dzieci i młodzieży opublikowane przez Margaret Mead w 1928 r. Jest ono jednym z najbardziej znanych przykładów stosowania pojęcia kultury w celu uwidocznienia przyjmowanych za pewnik modeli kulturowych Zachodu. W badaniach etnograficznych, prowadzonych w czasie nasilonej debaty publicznej w Stanach Zjednoczonych na temat problemów psychologicznych i edukacyjnych amerykańskiej młodzieży, Mead wykazuje, że pojęcie dojrzewania jako etapu życia nie występuje na Samoa, gdzie dziewczęta przechodzą gładko od dzieciństwa do dorosłości, co dowiodło kulturowej konstrukcji pojęcia dojrzewania. Autorka powołuje się na swoje badania etnograficzne, aby skrytykować północnoamerykańskie wzorce wychowania. We wstępie do swojej książki pisze: „Największą uwagę poświęcimy różnicom, jakie dzielą wychowanie samoańskie, w najszerszym jego sensie, od naszego wychowania. Wychodząc od tych różnic, będzie- 
my mogli zawrócić - zyskując świeżą, żywą i krytyczną świadomość naszych metod i ponownie osądzić, a może inaczej ukierunkować wychowanie naszych dzieci” (Mead 1986: 28). Klasyczna etnografia Mead, napisana przy wykorzystaniu pozytywistycznego paradygmatu, podobnie jak etnografia systemu wymiany na Wyspach Trobrianda Bronisława Malinowskiego, jest doskonałym przykładem zdolności antropologii do krytyki kulturowej. Opisując całkowicie odmienne style życia, ujawnia ona kulturowo konstruowaną naturę zachodnich modeli etapów życiowych i wychowania. Koncepcja kultury, za którą się opowiada, jest oczywiście modelem zamkniętym i dyskretnym - opiera się na badaniu odległego Innego w celu naświetlenia realiów społecznych kultury amerykańskiej.

George Spindler, jeden z założycieli CAE, jest autorem wielu ważnych studiów na temat kulturowych aspektów edukacji i wychowania. W swoim znanym badaniu z $1974 \mathrm{r}$. posługuje się przykładami z różnych kultur spoza świata Zachodu, ilustrującymi, jak w procesach wychowania i kształcenia zasadnicze wartości i cechy kulturowe są przekazywane z pokolenia na pokolenie. Posługując się tymi przykładami, autor stwierdza, że cała edukacja może być rozumiana jako proces kulturowej transmisji. W swoim tekście posługuje się ważnymi dla antropologii kategoriami, takimi jak rytuały i inicjacje, które towarzyszą przejściu z jednego etapu życia do następnego, i wprowadza ważne pojęcia, takie jak kulturowa kompresja, kulturowa ciągłość i nieciągłość. Choć pojmowanie kultury przez Spindlera w jego wczesnych tekstach jest raczej statyczne i zamknięte w odległych geograficznie lokalizacjach, przedstawiony przez niego eklektyczny obraz praktyk wychowawczych z różnorodnych środowisk umieszcza wczesne dzieciństwo w centrum debaty wokół kulturowo konstruowanej podstawy wychowania i procesów edukacyjnych. Od tamtej pory antropolodzy dostarczyli wielu badań etnograficznych na temat szkolnictwa i wychowania dzieci w różnorodnych kontekstach kulturowych, pogłębiając rozumienie konstruowanej natury formalnych i nieformalnych procesów edukacyjnych. Pełniejszy wybór przykładów można znaleźć w pracach: A Companion to the Anthropology of Education pod redakcją Bradleya Levinsona i Miki Pollock (2011), Anthropologies of Education: A Global Guide to Ethnographic Studies of Learning and Schooling pod redakcją Kathryn Anderson-Levitt (2012) oraz w artykułach zamieszczonych w wiodącym czasopiśmie naukowym „Anthropology \& Education Quarterly”. Spośród niedawnych reprezentatywnych przykładów polskich należy wspomnieć etnografię edukacyjną Tarzycjusza Bulińskiego (2018), opartą na jego rozległych badaniach narodu Enepa w Wenezueli.

\section{Praktyka szkolna a struktury nierówności}

Ważnym obszarem zainteresowania antropologów edukacyjnych jest edukacja szkolna oraz sposób, w jaki różnice społeczne i nierówności są zarówno powielane, jak i podważane w procesie nauczania szkolnego. Wyjątkowość wkładu antropologii w badania szkoły polega na jej koncentracji na podmiotach marginalizowanych - na Innym - oraz na tym, jak dominujące, kulturowe wzorce szkolnictwa i procesu nauczania sprzyjają defaworyzowaniu dzieci i młodzieży ze środowisk mniejszościowych i imigranckich. 
Przyjmując perspektywę z marginesu - punkt widzenia tubylca - w badaniach tych ukazuje się niewidoczne i nierzadko nieświadome procesy wykluczania, które przenikają szkolne rzeczywistości.

Prawdziwym klasykiem w tej dziedzinie jest studium kulturowej terapii George'a i Louisy Spindlerów, oparte na etnografii amerykańskiej szkoły (Spindler, Spindler 2019). Spindlerowie analizują w nim przypadek Rogera Harkera - nauczyciela cieszącego się wielką renomą wśród współpracowników i kierownictwa, który na ochotnika zgłosił się do antropologicznych badań obserwacyjnych przez nich prowadzonych. Ku zdziwieniu Harkera Spindlerowie w badaniu wykazali, że był on nielubiany przez wielu swych uczniów, którzy pochodzili z innej warstwy społecznej i kultury niż on i którzy uważali jego działania za dyskryminujące. W procesie terapii kulturowej - metody, za pomocą której antropologowie ujawnili kulturowe źródła dyskryminujących zachowań nauczyciela - Spindlerowie, w duchu tradycji antropologicznej, uwidocznili nauczycielowi kulturę, w której był zakotwiczony i która była dla niego do tej pory niewidoczna. Studium Spindlerów wraz z ich koncepcją terapii kulturowej stanowią wczesny przykład badań zaangażowanych w antropologii edukacyjnej. Spindlerowie przekraczają granicę zdystansowanej obserwacji i dzielą się swoimi odkryciami z praktykami w celu wprowadzenia zmian.

Niewidzialność kultury jako ukrytego mechanizmu szkolnych praktyk wykluczania jest również tematem innej klasycznej pracy, skupiającej się na społeczno-kulturowych kontekstach niepowodzenia szkolnego grup zmarginalizowanych. W studium Osiaganie niepowodzeń szkolnych Ray McDermott (2019) poszukuje odpowiedzi na zasadnicze pytanie dotyczące edukacji, a mianowicie - w jaki sposób szkoła przyczynia się do reprodukcji nierówności społecznych. W swoim wywodzie McDermott dekonstruuje dwa esencjalizujące stwierdzenia najczęściej przytaczane do wyjaśnienia słabych wyników w nauce uczniów z pewnych grup: 1) dzieci z grup mniejszościowych nie uczą się dobrze, a hamuje je ich kultura; 2) nauczyciele świadomie dyskryminują dzieci z grup mniejszościowych, przyczyniając się w ten sposób do ich porażek edukacyjnych. McDermott odrzuca oba te wnioski i wykazuje, że w przeważającej mierze to nieuświadomione i niewidoczne procesy komunikacji właściwe danej kulturze przebiegające między nauczycielami - przedstawicielami państwa - a uczniami o różnych społecznych i kulturowych korzeniach przyczyniają się do ich sukcesów i porażek szkolnych, które z kolei decydują o ich przyszłych losach w społeczeństwie. Opracowanie to jest szczególnie ważne, ponieważ wykazuje, że ani nauczyciele, ani uczniowie nie są świadomi kulturowego ,zaprogramowania" leżącego u podstaw procesów edukacyjnych.

Ważnym obszarem badań edukacyjnych studiów antropologicznych jest dziedzina języka i piśmienności - szczególnie silnie reprezentowana przez badania wczesnej edukacji. W języku polskim dostępne jest klasyczne studium Shirley Brice Heath (2019), lingwistki i antropolożki edukacyjnej, która przeprowadziła badanie etnograficzne wpływu sposobu posługiwania się językiem w rodzinach na sukces dzieci w szkołach. Badania prowadzone przez Heath wraz z nauczycielami w czasie tuż po desegregacji amerykańskiego Południa wskazują na silny wpływ praktyk językowych rodzin na osiągnięcia szkolne dzieci. Co 
ważne, dzięki metodologii uczestniczącej, którą przyjęła Heath, współprowadzący badania nauczyciele wykorzystywali wiedzę uzyskaną w trakcie badania etnograficznego do prób wyrównania szans osiągnięcia sukcesu szkolnego uczniów, którzy byli społecznie i językowo defaworyzowani w tradycyjnym programie nauczania. $\mathrm{W}$ tym wczesnym przykładzie badań uczestniczących Heath wskazuje, że nauczyciele i szkoły mają możliwość tworzenia nowych ścieżek edukacji dla dzieci ze środowisk mniejszościowych.

Współczesne antropologiczne studia szkolnych rzeczywistości przyjmują bardziej dynamiczną i procesualną koncepcję kultury i pomagają też zrozumieć, w jaki sposób dzieci i młodzież w szkołach negocjują procesy kształtowania kulturowych i politycznych tożsamości w zderzeniu z edukacją szkolną jako zinstytucjonalizowanym procesem produkcji i transmisji kultury większościowej. Za przykład mogą służyć prace Bradleya Levinsona (2019), Beth Rubin (2019) i Thei Abu El-Haj (2019), których autorzy dowodzą, jak młodzież w meksykańskich i północnoamerykańskich szkołach średnich dochodzi do sprawczości i przejmuje kontrolę nad procesami kształtowania tożsamości w zderzeniu z dominującą polityką realizowaną w szkołach. Levinson (2019) w swoich badaniach m.in. pokazuje, jak młodzież z defaworyzowanych środowisk społecznych, uczęszczająca do meksykańskiej szkoły średniej, której celem było zatarcie społecznych różnic między uczniami, doświadcza sprzeczności między światem szkoły a światem własnej społeczności, co może prowadzić do porzucenia szkoły. Podobnie Rubin (2019), pisząc o społecznie i etnicznie zróżnicowanej młodzieży uczącej się w amerykańskich szkołach średnich, naświetla obszary zbieżności i rozziewu między szkolnym programem a codziennym doświadczeniem uczniów, które mają dogłębny wpływ na kształtowanie ich tożsamości obywatelskiej. Thea Abu El-Haj (2019) w swojej etnograficznej analizie, opartej na uczestniczących badaniach w działaniu, bada dyskryminację palestyńskiej młodzieży w amerykańskich szkołach średnich, szczególnie nasilającą się po ataku na World Trade Center 11 września 2001 r. Autorka pokazuje, jak z mechanizmów i działań, podejmowanych w szkole pod wpływem państwowej polityki wobec krajów islamskich, wyłania się symboliczna i słowna dyskryminacja Amerykanów pochodzenia arabskiego w kontekście nasilającego się amerykańskiego nacjonalizmu. Szczególnie ważny pod kątem moich rozważań nad zmieniającym się kształtem pojęcia kultury w antropologicznych badaniach edukacyjnych jest opisany przez Abu El-Haj konflikt kulturowy i tożsamościowy, którego palestyńsko-amerykańska młodzież doświadcza w zderzeniu ze szkolną rzeczywistością w kontekście globalizacji i światowej migracji. Abu El-Haj wykazuje, że transnarodowe doświadczenia palestyńskiej młodzieży zderzają się z narodowo powiązanym programem nauczania w amerykańskiej edukacji szkolnej, rodząc konflikt pomiędzy ich poczuciem przynależności do narodu palestyńskiego a ich amerykańskim obywatelstwem. Prace Abu El-Haj i Rubin są również współczesnymi przykładami silnej tradycji uczestniczących badań w działaniu w antropologicznych badaniach edukacyjnych, co dokładniej przedstawiłam w następnej części. 


\section{Uczestniczace i wspótpracujące podejścia badawcze}

Jednym z najbardziej inspirujących obszarów edukacyjnych badań antropologicznych są przykłady uczestniczących i współpracujących badań prowadzonych przez badaczy akademickich wraz z nauczycielami - badaczami praktykami - jak również innymi członkami wspólnoty szkolnej. Zdaję sobie sprawę, że wielu autorów tekstów, które do tej pory przytoczyłam, stosuje uczestniczące badania w działaniu - począwszy od terapii kulturowej Spindlerów, poprzez wspólną rodzinno-szkolną etnografię Heath, a kończąc na badaniach amerykańskiej młodzieży szkół średnich przeprowadzonych przez Rubin i Abu El-Haj. Kolejne przykłady inspirujących, zaangażowanych badań w antropologii edukacji miały na celu uwypuklić ich kluczową i rosnącą rolę w tej interdyscyplinarnej tradycji naukowej (Henze 2020).

Jednym z wczesnych i najważniejszych przykładów podejścia, które łączy etnografię i uczestniczące badania w działaniu, są prace Fredericka Ericksona, szczególnie jego artykuł Badania ręka w rękę (2019). Antropolog pokazuje w niej proces prowadzenia badań wspólnie przez badaczy akademickich, nauczycieli i rodziców jako „alternatywę dla elitarności etnografii tradycyjnej oraz najpowszechniejszego, opartego na naukach ścisłych modelu badań edukacyjnych w służbie polityki" (Erickson 2019: 271). Praca Ericksona to inspirujący przykład współdziałania badaczy akademickich i nauczycieli przy badaniach, które wprowadza zmiany społeczne oraz podważa dychotomię między nauką akademicką a światem praktyki.

W przełomowej pracy Normy Gonzáles i Luisy Moll z zespołem (2019), w której zostało wprowadzone kluczowe pojęcie „zasoby wiedzy” do tradycji antropologicznych badań edukacyjnych, autorzy pokazali, że w nauczaniu wrażliwym na kulturę trzeba uwzględnić rodzinne i wspólnotowe korzenie uczniów. Gonzáles i Moll zachęcają nauczycieli do przyjęcia roli badaczy światów swoich uczniów, co umożliwi im nauczanie, w którym zarówno treści przekazywane uczniom, jak i sposób ich prezentowania będą dla nich istotne. Koncepcja „zasobów wiedzy” jest jedną z najbardziej nośnych ram w antropologiczno-edukacyjnych uczestniczących badaniach poszerzających wspólnotę szkolną o rzeczywistą współpracę szkoły i rodziny.

Ostatnim przykładem są znane już w Polsce prace Pauline Lipman $(2010,2019)$ - antropolożki edukacyjnej z Chicago, która w swojej pracy wskazuje kolejny otwarcie polityczny sposób zaangażowania antropologów i pedagogów w walkę o sprawiedliwość społeczną. W swoich tekstach Lipman przytacza przykłady konkretnych projektów badań w działaniu, w ramach których nauczyciele, rodzice, uczniowie, naukowcy i społecznicy zawiązują sojusz w proteście przeciwko ekonomicznie i politycznie motywowanej akcji zamykania szkół - jej skutki zagrażają egzystencji chicagowskich wspólnot mniejszościowych i imigranckich. Teksty Lipman wyjątkowo dobitnie uwypuklają powiązania między ocenianiem (szkół i w szkołach), zamykaniem szkół i polityką miejską. Stanowią one ważny przykład tego aspektu antropologicznych badań etnograficznych, który potwierdza ich zdolność do interpretacyjnego łączenia mikro- i makrokulturowej analizy rzeczywistości społecznej i politycznej (Lipman 2010, 2019). 


\section{Wnioski}

W niniejszym artykule skoncentrowałam się na kluczowym dla antropologii edukacyjnej pojęciu „kultura” w celu pokazania jego zastosowania przez antropologów edukacyjnych (głównie w tradycji północnoamerykańskiej) jako krytycznego spojrzenia na społeczno-kulturową kontekstualizację edukacji formalnej i nieformalnej. Celem artykułu, w którym odwołałam się głównie do przykładów tekstów publikowanych ostatnio w języku polskim, jest usytuowanie perspektywy antropologii edukacyjnej w polskim dyskursie naukowym. W mojej wcześniejszej pracy jako nauczycielki akademickiej w Polsce posługiwałam się przytoczonymi tekstami, aby pomóc moim studentom w określaniu społecznych realiów ich pracy oraz świata społecznego w ujęciu wielokulturowym i międzykulturowym (Červinková 2019a). Z mojego doświadczenia wynika, że rzeczywistość krajów postsocjalistycznych, takich jak Polska czy Republika Czeska, wygląda zupełnie inaczej mimo promowanej przez nie iluzji kulturowej jednorodności. Doświadczenia moich studentów-nauczycieli wskazują na zróżnicowanie doświadczeń i potrzeb uczniów związane z nasilającymi się procesami globalizacji oraz ich wpływem na codzienność szkolną (Červinková 2019b). W tej zmiennej rzeczywistości perspektywa antropologiczna, która sprzyja międzykulturowo wrażliwemu, pedagogicznemu umiejscowieniu badań, może być użyteczna w podejmowaniu wyzwań różnorodności społeczno-kulturowej oraz - jak wierzę - może pomóc w tworzeniu bardziej inkluzyjnych wspólnot szkolnych.

Przekład: Tomasz Woźniak

\section{Literatura}

Abu El-Haj T.R. (2019), „Urodzitem się tutaj, ale mój dom jest gdzie indziej”. Kształcenie do demokratycznego obywatelstwa w epoce transnarodowych migracji i globalnego konfliktu. W: Červinková H. (red.), Antropologia i edukacja. Etnograficzne badania edukacyjne w tradycji amerykańskiej. Wrocław, Wydawnictwo Naukowe Dolnośląskiej Szkoły Wyższej.

Abu-Lughod L. (2014), Writing Against Culture. W: H.L. Moore, T. Sanders (eds.), Anthropology in Theory. Issues in Epistemology. New York, Wiley \& Blackwell.

Anderson-Levitt K. (2012), Anthropologies of Education: A Global Guide to Ethnographic Studies of Learning and Schooling. New York, Berghahn Books.

Buliński T. (2018), Szkoła w Amazońskiej Puszczy. Gdańsk, Wydawnictwo Uniwersytetu Gdańskiego. Červinková H. (red.) (2019a), Antropologia i edukacja. Etnograficzne badania edukacyjne w tradycji amerykańskiej. Wrocław, Wydawnictwo Naukowe Dolnośląskiej Szkoły Wyższej.

Červinková H. (2019b), Nauczanie i uczenie się antropologii w edukacji nauczycieli. W: H. Červinková (red.), Antropologia i edukacja. Etnograficzne badania edukacyjne w tradycji amerykańskiej. Wrocław, Wydawnictwo Naukowe Dolnośląskiej Szkoły Wyższej.

Clifford J. (2000), Kłopoty z kultura. Warszawa, Wydawnictwo KR. 
Clifford J., Marcus G. (1986), Writing Culture: The Poetics and Politics of Ethnography. Los Angeles, University of California Press.

Erickson F. (2019), Badania ręka w rękę. Uczestnicząca etnografia w działaniu jako część badań edukacyjnych. W: H. Červinková (red.), Antropologia i edukacja. Etnograficzne badania edukacyjne w tradycji amerykańskiej. Wrocław, Wydawnictwo Naukowe Dolnośląskiej Szkoły Wyższej.

Geertz C. (2005), Opis gęsty - w strone interpretatywnej teorii kultury. W: M. Kempny, E. Nowicka (red.), Badanie kultury: Elementy teorii antropologicznej. Warszawa, Wydawnictwo Naukowe PWN.

Gonzáles N. (2010a), Advocacy Anthropology and Education: Working through the Binaries. „Current Anthropology”, 51(S2): Engaged Anthropology: Diversity and Dilemmas.

Gonzáles N. (2010b), What Will We Do When Culture Does Not Exist Anymore? „Anthropology \& Education Quarterly", 30(4).

Gonzáles N., Moll L.C., Tenery M.F., Rivera A., Rendon P., Gonzáles R., Amanti C. (2019), Latynoskie domostwa i wykorzystywanie ich zasobów wiedzy w nauczaniu. W: H. Červinková (red.), Antropologia i edukacja. Etnograficzne badania edukacyjne $w$ tradycji amerykańskiej. Wrocław, Wydawnictwo Naukowe Dolnośląskiej Szkoły Wyższej.

Gupta A., Ferguson J. (2005), Poza „,kulturę”: przestrzeń, tożsamość i polityka różnicy. W: M. Kempny, E. Nowicka (red.), Badanie kultury: Elementy teorii antropologicznej. Warszawa: Wydawnictwo Naukowe PWN.

Hannerz U. (2003), Being there... and there... and there! Reflections on multi-site ethnography. „Ethnography”, 4(2).

Hannerz U. (2010), Anthropology's World life in a Twenty-First-Century Discipline. London, Pluto Press.

Heath S.B. (2019), Osiaganie szkolnych niepowodzeń: antropologiczne podejście do analfabetyzmu i stratyfikacji społecznej. W: H. Červinková (red.), Antropologia i edukacja. Etnograficzne badania edukacyjne w tradycji amerykańskiej. Wrocław, Wydawnictwo Naukowe Dolnośląskiej Szkoły Wyższej.

Henze R. (2020), Anthropology of Education, Oxford Research Encyclopedias. Oxford, Oxford University Press. https://doi.org/10.1093/acrefore/9780190854584.013.10, 14.09.2020.

Levinson B. (2019), Różnice społeczne a tożsamość osoby wyedukowanej w meksykańskiej szkole średniej, W: H. Červinková (red.), Antropologia i edukacja. Etnograficzne badania edukacyjne w tradycji amerykańskiej. Wrocław, Wydawnictwo Naukowe Dolnośląskiej Szkoły Wyższej.

Levinson B., Pollock M. (eds.) (2011), A Companion to the Anthropology of Education. Malden, MA, Wiley-Blackwell.

Lewis O. (1959), Five families. Mexican case studies in the culture of poverty. New York, Basic Books.

Lipman P. (2010), Etnografia edukacyjna i polityka globalizacji, wojny i oporu. W: H. Červinková, B.D. Gołębniak (red.), Badania w działaniu. Pedagogika i antropologia zaangażowane. Wrocław, Wydawnictwo Naukowe Dolnośląskiej Szkoły Wyższej.

Lipman P. (2019), W opozycji do miasta. Neoliberalny urbanizm i kulturowa polityka reformy szkolnictwa w Chicago. W: H. Červinková (red.), Antropologia i edukacja. Etnograficzne badania edukacyjne w tradycji amerykańskiej. Wrocław, Wydawnictwo Naukowe Dolnośląskiej Szkoły Wyższej.

Malinowski B. (2005), Argonauts of the Western Pacific. An Account of Native Enterprise and Adventure in the Archipelagoes of Melanesian New Quinea. New York, Taylor \& Francis e-Library. 
Marcus G.E., Fischer M.M.J. (2010), Repatriacja antropologii jako krytyki kulturowej. W: H. Červinková, B.D. Gołębniak (red.), Badania $w$ działaniu. Pedagogika i antropologia zaangażowane. Wrocław, Wydawnictwo Naukowe Dolnośląskiej Szkoły Wyższej.

McDermott R.P. (2019), Osiaganie szkolnych niepowodzeń: antropologiczne podejście do analfabetyzmu i stratyfikacji społecznej, W: H. Červinková (red.), Antropologia i edukacja. Etnograficzne badania edukacyjne w tradycji amerykańskiej. Wrocław, Wydawnictwo Naukowe Dolnośląskiej Szkoły Wyższej.

Mead M. (1986), Dojrzewanie na Samoa. Warszawa, Państwowy Instytut Wydawniczy.

Rubin B., Hayes B.F. (2019), ,Z Zlecakami nie wolno” a „,Narkotyki i zabójstwa”. Potencjat i złożoność obywatelskich badań w działaniu z młodzieża. W: H. Červinková (red.), Antropologia i edukacja. Etnograficzne badania edukacyjne w tradycji amerykańskiej. Wrocław, Wydawnictwo Naukowe Dolnośląskiej Szkoły Wyższej.

Spindler G. (2019), Transmisja kulturowa. W: H. Červinková (red.), Antropologia i edukacja. Etnograficzne badania edukacyjne w tradycji amerykańskiej. Wrocław, Wydawnictwo Naukowe Dolnośląskiej Szkoły Wyższej.

Spindler G., Spindler L. (2019), Roger Harker i Schönhausen. Od znanego do obcego. W: H. Červinková (red.), Antropologia i edukacja. Etnograficzne badania edukacyjne w tradycji amerykańskiej. Wrocław, Wydawnictwo Naukowe Dolnośląskiej Szkoły Wyższej.

Vertovec S. (2011), The Cultural Politics of Nation and Migration. „Annual Review of Anthropology", 40.

Wagner R. (2005), Wynalezienie kultury. W: M. Kempny, E. Nowicka (red.), Badanie kultury: Elementy teorii antropologicznej. Warszawa, Wydawnictwo Naukowe PWN.

Wolcott H.F. (2008), Ethnography: A Way of Seeing. Lanham, MD, AltaMira Press, Rowman \& Littlefield Publishers, Inc. 